УДК 316.658.4:316.46.058.5]:316.472.4

DOI https://doi.org/10.32837/apfs.v0i29.963

Т.О.Ратушна

ORCID ID: https://orcid.org/0000-00010-7351-6647

кандидат соиіологічних наук,

доиент кафедри соиіології

Запорізького національного університету

\title{
ФЕЙКИ ЯК МАНІПУЛЯТИВНА ТЕХНОЛОГІЯ ФОРМУВАННЯ ГРОМАДСЬКОЇ ДУМКИ
}

Постановка проблеми. У сучасному світі інформація набуває все більшого значення, а сам інформаційний простір постійно розвивається. Спостерігається поява нових медіа й каналів комунікації, які використовують нові технології та швидко розповсюджуються в суспільстві, продукуючи величезну кількість інформації. Засоби масової інформації (далі - ЗМI) минулого століття, та журналістська діяльність взагалі, були спрямовані на те, щоб викласти певні факти й допомогти людині розібратись і зорієнтуватись у численній масі соціальних подій. Саме 3MI формували громадську думку, транслювали й утверджували систему соціальних цінностей, зразків поведінки тощо. Однак із розвитком масових комунікацій і технологій у цій сфері відбулись суттєві зміни й виявилися нові тенденції. Наприклад, на заміну друкованим газетам і журналам прийшли їх електронні верciї (яскравіші, постійно доступні й набагато оперативніші з боку реакції на інформаційний привід і поширення інформації) та соціальні мережі, які дають змогу користувачам не тільки знаходити необхідну інформацію, а й обговорювати їі, висловлювати власну думку тощо.

Частка соціальних мереж в інформаційному просторі постійно зростає та, окрім виконання суто комунікативної та розважальної функції, вони набувають значення важливого джерела отримання інформації про події, що відбуваються в суспільстві. Інститут досліджень журналістики Reuters відзначає глобальну тенденцію, яка полягає в тому, що $51 \%$ користувачів Інтернету використовують соціальні мережі як джерело новин (дослідження, яке проводиться вже 5 років, засноване на опитуванні YouGov близько 50000 осіб у 26 країнах) [1]. Ці дані вказують на те, що соціальні мережі випереджають навіть телебачення як джерело новин, особливо це характерно для молоді. До того ж за останні $5-10$ років доступ до мережі також змінився: від стаціонарних пристроїв на роботі чи вдома користувачі перейшли до мобільних телефонів і смартфонів. За даними дослідницького холдингу Factum Group Ukraine в Україні із 71\% регулярних користувачів Інтернету (приблизно 23 млн осіб) 66\% використовують мобільні пристрої (смартфон і мобільний телефон)
[2], тобто мають можливість постійно перебувати в інформаційному просторі.

Ще однією важливою характеристикою сучасного інформаційного й медіапростору стала постійно зростальна чисельність інформаційних повідомлень, адже тепер кожен користувач Інтернету може стати не просто їх споживачем, а й автором, у результаті можна спостерігати як значну інтенсифікацію комунікативних потоків, так і погіршення якості інформації, що швидко розповсюджується в мережі. Звичайно, традиційні 3MI можуть виробляти якісніший контент (за умови, що дотримуються стандарти журналістської діяльності й професійної етики), на відміну від соціальних мереж, де безліч повідомлень, які можуть містити як правдиву, так i хибну інформацію.

Соціальні мережі нині - це величезний сегмент комунікативного простору, однак це ще й саморегульоване середовище, що майже не контролюється та не піддається цензуруванню, неперевірена або спотворена інформація може активно розповсюджуватись і впливати на формування громадської думки. Тож головна складність полягає нині не в тому, щоб отримати певну інформацію чи прочитати новини, а в тому, щоб визначити, яка інформація є потрібною та правдивою, а яка - шкідливою та спотвореною.

Аналіз досліджень і публікацій. Особливості формування громадської думки й маніпулятивних впливів на неї розглядаються в доробках вчених різних галузей знань (соціологія, психологія, соціальні комунікації, політологія тощо), що вказує на важливість міждисциплінарного підходу до вивчення феномену. Серед найбільш грунтовних праць, присвячених інформаційним і комунікативним впливам, що стали поштовхом для подальших наукових розробок, стали роботи Г. Тарда, П. Лазарсфельда, Г. Олпорта, В. Ліппмана, М. Маклюена, Е. Ноель-Нойман, Р. Кнеппа, Л. Постмена, А. Хореса й багатьох інших. Особливо в такому контексті варто відзначити роботу М. Кастельса з колегами «Мобільні комунікації та суспільство: глобальні перспективи", що розглядає в тому числі й ключові питання щодо перетворення суспільства на «суспільство мобільної мережі» й становлення нової мобільної 
культури, заснованої на однорангових мережах, iз власною мовою текстових повідомлень і власними цінностями й відповідні політичні, соціальні й економічні наслідки таких процесів. Важливим внеском у розуміння інформаційної безпеки в сучасному суспільстві $€$ також праці Г. Почепцова, С. Кара-Мурзи, Я. Кальби, В. Москаленко, М. Костельнюк. Однак водночас можна відзначити, що, попри значну увагу до проблематики в науковій i науково-популярній літературі, питання поширення фейків в інформаційно-комунікаційному просторі, механізми їх впливу на аудиторію та способи ідентифікації та запобігання вивчені недостатньою мірою.

Метою статті $€$ на основі теоретичного аналізу й використання конкретних кейсів визначити маркери фейків для їх ідентифікації в інформаційно-комунікаційному просторі й окреслити можливі шляхи запобігання їх поширенню.

Виклад основного матеріалу. Особливості сучасного інфопростору (велика кількість повідомлень, різні канали інформування, швидкість оновлення інформації, анонімність авторів тощо) створюють для користувачів певні загрози, наприклад, загроза повірити брехливій, фейковій інформації, стати жертвою маніпулятивних впливів, тож актуалізується питання ідентифікації фейків і вивчення технологій їх створення та розповсюдження.

Взагалі термін фейк(и) не є сталим у науковій думці й використовується для позначення досить широкого кола феноменів. Fake 3 англійської мови перекладається як «підробка», «обман». Фейками чи фейковими називають фотографії, оброблені в фоторедакторах; відеоролики, змонтовані в редакторах відео; сторінки в соціальних мережах, створені від імені інших (як правило, відомих) людей; неправдиві чи анекдотичні істоpiï, які поширюють розважальні ресурси тощо. Однак, як зазначає Ю. Сршов, у контексті досліджень формування інформаційного поля та стрічок новин поняття «фейк» розглядається як цілеспрямоване використання вигаданих і спеціально сфабрикованих новин, головною метою яких є підрив репутації будь-якого соціального інституту, організації або персони. Також дослідник вказує на основну мету таких повідомлень, що спрямовані на дискредитацію кого-небудь чи чого-небудь для того, щоб не просто зганьбити, а й отримати від цього якусь вигоду (наприклад, політичну або економічну) [3, с. 247].

У зв' язку зі значним поширенням фейків виникає потреба в їх ідентифікації та нейтралізації, аналізі й верифікації інформаційних повідомлень. О. Курбан вказує, що в Україні цим займаються державні структури: Міністерство внутрішніх справ (Департамент кіберполіції в складі Національної поліції України), Служба безпеки Укра- їни (Департамент контррозвідувальної діяльності із захисту національної безпеки в інформаційній сфері), Міністерство оборони України (Департамент інформаційно-організаційної роботи, Управління інформаційних технологій, Відділ координації стратегічних комунікацій і моніторингу) [4, с. 99].

Також діяльність щодо боротьби 3 фейками здійснюють і громадські організації та об'єднання, що займаються просвітницькою діяльністю: «Детектор Медіа», "StopFAKE", "VoxUkraine”, «Інститут масової інформації», проєкт «По той бік новин» тощо. Для кращого розуміння феномену вони розбирають конкретні кейси, вивчення яких дає можливість глибшого й детальнішого аналізу природи, латентних механізмів і технологій розповсюдження та використання фейків.

Один із таких кейсів стосується політичної сфери, оскільки саме тут спостерігається значний обсяг неправдивої інформації, що значною мірою пов'язано 3 активністю політичних процесів i боротьбою за увагу й прихильність масової аудиторіï.

У жовтні 2020 року медіа дослідники й журналісти О. Братущак та О. Романюк опублікували результати аналізу новини 23 загальнонаціональних онлайн-медіа, які виходили протягом 7-9 вересня 2020 року, в цьому масиві вони виявили 150 фейків і 461 маніпуляцію. Серед них основними темами були побутові (39\% - забобони, магія, прогнози ноунейм-астрологів щодо всіх аспектів життя або «політична астрологія»), проросійські (34\%) і фейки, пов'язані з місцевими виборами $(12 \%)$ [5].

Детально розглянувши ці випадки, можна побачити певні особливості створення та розповсюдження фейків.

По-перше, фейки виникають у тих ситуаціях i сферах життя, де існує певний «інформаційний вакуум», тобто $є$ нестача офіційної правдивої інформації або її важко перевірити (наприклад, щодо ухвалення політичних рішень чи даних, що стосуються воєнних дій). Ще одним чинником, характерним для українського суспільства, може бути зниження довіри в суспільстві до владних інститутів та офіційних джерел.

За даними соціологічного дослідження, проведеного соціологічною службою Центру Разумкова з 13 по 17 лютого 2020 року, Верховній Раді України у вересні 2019 року довіряли 57\% опитаних, не довіряли - 25\%, у лютому 2020 року відповідно 28\% і 65\%. Уряду у вересні 2019 року довіряли $57 \%$ респондентів, не довіряли - $22 \%$, у лютому 2020 року - відповідно 28\% і 64,5\% [6].

Дані опитування USAID-Internews щодо споживання медіа вказують на зниження довіри й до загальнонаціональних медіа. Найбільше у 2020 році втратили довіру аудиторії національні й 
регіональні телеканали (із 61\% і 51\% у 2015 році до $41 \%$ і $38 \%$ у 2020 році), натомість для отримання новин споживачі найчастіше віддають перевагу інтернет-службам і сервісам новин. Серед соціальних мереж як джерела новин першу позицію займає Facebook (47\% користувачів). Українці стали активніше використовувати YouTube як альтернативу телебаченню $(30 \%)$ і месенджери Telegram i Viber (21\% i 18\%) для отримання коротких новин, можливості бути в курсі подій [7]. Така «криза довіри» населення до владних інститутів та офіційних медіа й переорієнтація на соціальні мережі як основне джерело інформації (де більшість повідомлень створюється самими користувачами й часто не піддається перевірці й верифікації) є одним із факторів виникнення та поширення неправдивої інформації.

По-друге, часто сам заголовок вже має ознаки маніпуляції, бо спрямований на формування в читача негативних емоцій (обурення, тривоги й страху). Це пов'язано з тим, що часто через брак часу й велику кількість інформаційних повідомлень у стрічках новинних сайтів і соціальних мереж користувач читає тільки їх заголовки й, звичайно, увагу будуть привертати більш емоційно забарвлені, шокові й сенсаційні з них.

Іншим важливим моментом є те, що повідомлення нібито грунтується на реальній інформації, однак більша частина повідомлення побудована на домислах і перекручуванні фактів. Зміст повідомлення також характеризується частіше за все емоційно-негативним забарвленням, матеріал подається однобоко, часто не зрозуміло, яким чином автор доходить тих чи інших висновків, та й сам автор не вказується.

Ще однією ознакою фейку є посилання на «експертів», «анонімні джерела», «наближених осіб», яких не можна ідентифікувати, а відповідно й перевірити надійність і правдивість наданої інформації. Схожа ситуація із застосуванням таких фраз, як «загальновідомо», «очевидно», «без сумнівів», «науково доведено». Подібні прийоми без аргументації та деталізації є «готовими до споживання» твердженнями й не передбачають критичного осмислення, а навпаки, ніби надають додаткової ваги й авторитету.

Ще одним цікавим кейсом є розповсюдження із січня 2020 року фейку про поширення COVID-19 через мережу $5 \mathrm{G}$, який переріс у справжню конспірологічну теорію та розповсюджувався в багатьох країнах. У такому випадку також можна відзначити основні передумови виникнення фейку: брак офіційної інформації (недостатня вивченість причин виникнення та замовчування певний час масштабів та особливостей поширення COVID-19), «чутливість» громадської думки щодо цієї проблеми, бо вона викликає значний емоційний резонанс через страх населення за життя та здоров'я своє і близьких. Сам фейк мав сенсаційні заголовки, його зміст був емоційно-негативно забарвлений, використовувались посилання на певні факти (наприклад, що в китайському місті Ухань, де й було виявлено перші випадки зараження, діє мережа 5G), однак потім додавалась вигадана й неперевірена інформація, в деяких варіаціях фейку додавали думки «експертів» (ними виступали конспірологи й антивакцинатори).

Австралійський дослідник А. Брюнс із колегами детально вивчив цей випадок і з'ясував, що він виник не випадково, а скоріше з метою створення розділення думок і протестів у суспільстві. Це негативно впливає на політичну й економічну сфрери [8]. Цей кейс також важливий для розуміння технології розповсюдження фейків. Спочатку він виник як пост у мережі Twitter, в якому давалась інформація про наявність у м. Ухань мережі 5G та ставилось питання про те, чи там дійсно захворювання - це наслідок дії 5G станцій, також пов'язувались хештеги «\#Китай», «\#хвороба» й «\#5G». Надалі це повідомлення поширювалось у соціальних мережах (в основному Facebook, а також YouTube, Instagram i TikTok) і на Інтернет-порталах (блоги, новинні ресурси). Наступним етапом поширення стали інфлюенсери: зірки шоу-бізнесу й спорту, що мали велику кількість підписників у соціальних мережах, поширювали цю інформацію. Фейк мав реальні наслідки: так, в Австралії, Новій Зеландії, Великобританії та США відбувались протести проти встановлення станцій 5G, а деякі активісти здійснювали їх підпали. Органи влади цих країн і різноманітні факт-чекінгові організації намагались протидіяти дезінформації, постійно виступали 3 роз'ясненнями й вказували на бездоказовість і сумнівне походження подібних повідомлень, залучали науковців та експертів.

На офіційному сайті Всесвітньої організації охорони здоров'я для боротьби з фейками про COVID-19 було створено окремий розділ «Рекомендації ВОЗ для населення у зв'язку з поширенням нового коронавірусу (2019-nCoV): міфи й хибні уявлення", в якому міститься спростування того, що мобільні мережі $5 \mathrm{G}$ сприяють поширенню COVID-19. У повідомленні зазначено, що «віруси не переносяться 3 радіосигналом або хвилями мобільного зв'язку. Епідемія COVID-19 поширюється в багатьох країнах, де мережі $5 \mathrm{G}$ не розгорнуті» [9]. Однак навіть після викриття фейку й активної просвітницької кампанії частина тих, хто повірив у фейк, продовжують в нього вірити й залишаються прихильниками конспірологічних теорій змови.

У такому контексті фейки виступають як маніпуляції, що спрямовані на зміну громадської думки в потрібному для творця чи транслятора напрямі. Дійсно, якщо розглядати створення та розповсюдження фейків як цілеспрямовану 
діяльність із метою управління суспільними настроями, що має своєрідну логіку розгортання та містить певну послідовність етапів процедур та операцій, можна вважати, що це маніпулятивна технологія.

М. Костельнюк вказує, що технології маніпулювання передбачають використання багатого арсеналу конкретних методів впливу на свідомість людей. До них належать пряме підтасовування фактів, замовчування небажаної інформації, поширення брехні й наклепу, а також такі засоби, як напівправда (коли 3 метою забезпечення довіри аудиторії об'єктивно й докладно викладаються конкретні, малозначущі факти й одночасно замовчуються важливіші або ж подається хибна інтерпретація подій) [10, с. 131]. Усі ці методи досить різноманітні й можуть використовуватись не окремо, а в різних комбінаціях, тому постає питання ідентифікації фейкових маніпулятивних повідомлень. В узагальненому варіанті ознаками фейків можна вважати:

- поширення спрощеної інформації (як правило, у стверджувальній формі, що закликає до певної оцінки, а не до обговорення);

- фрагментарність (інформація подається не повністю, а уривками, чи містить скорочені висловлювання, а іноді факти, фрази чи зображення "вириваються» 3 контексту, що може призводити до їх неправильного розуміння аудитоpiєю);

- новизна й сенсаційність (такі повідомлення через їх звернення до актуальних подій і проблем настільки швидко привертають увагу користувачів і поширюються в мережі, що часто їх просто не встигають перевірити на правдивість, і такий контент може потрапляти навіть в офіційні джерела);

- емоційність (повідомлення концентрується не на фактичній складовій частині, а скоріше спрямоване на виклик в отримувача інформації певних емоційних реакцій, більшою мірою негативних, як-от страх, гнів, тривога тощо);

- повторення (містить як відтворення однієї та тієї ж думки декілька разів в одному повідомленні, так і його дублювання в різних джерелах, що створює враження загальновідомої інформації);

- використання посилань на ненаявних чи сумнівних експертів, анонімні джерела тощо;

- акцент на важливості якнайшвидше поширити повідомлення для «інформування» якомога більшої кількості осіб;

- спонукання до певних дій (чи відмови від них, як у випадку зі щепленнями).

Через значне поширення фейків у соціальних мережах під час президентської кампанії в США у 2016 році найбільші соціальні мережі вже почали маркувати деякі повідомлення як неправдиві. Наприклад, Facebook i Google видаляють сайти фейкових новин на тій підставі, що вони порушують політику щодо недопустимості оманливого вмісту. Крім того, Facebook вживає заходів для ідентифікації фальшивих новин (fake news) і спеціально маркує таку інформацію як неперевірену $[11$, с. 233]. Позначення неправдивих статей дозволяє показувати менше потенційно неправдивих повідомлень у стрічках новин і допомагає уникати випадкового обміну фейками, повідомляючи про те, що ця інформація не перевірена, перш ніж користувачі поділяться нею з іншими. Однак такі кроки щодо запобігання поширенню фейків хоч i необхідні, все ж не достатні для протидії навмисним дезінформаційним впливам і маніпуляціям громадською думкою.

Висновки. Беручи до уваги поширеність фейків як маніпулятивних технологій впливу на громадську думку, варто вивчати процеси їхнього створення та розповсюдження для ефективного протистояння, оскільки вони несуть загрозу не тільки для конкретного споживача інформації, а й для суспільства в цілому. Для цього необхідна системна робота на трьох основних рівнях:

- інституційному (діяльність державних структур, що забезпечують інформаційну безпеку, та їх законодавча підтримка);

- організаційному (тут важливими будуть два основні напрями: політика соціальних мереж щодо виявлення та видалення фейків і діяльність факт-чекінгових і просвітницьких організацій);

- індивідуальному (розвиток критичного мислення в користувачів і розуміння основних принципів інформаційної гігієни).

Майбутні дослідження в напрямі повинні дати ефективні методи й інструменти боротьби з фейками для мінімізації їхнього негативного впливу на громадську думку.

\section{Jimepamyра}

1. Соціальні мережі випередили телебачення як джерело новин для молоді. MediaSapiens. 16 червня 2016 p. URL: https://ms.detector.media/sotsmerezhi/ post/16814/2016-06-16-sotsialni-merezhi-vyperedylytelebachennya-yak-dzherelo-novyn-dlya-molodi/ (дата звернення: 02.04.2021).

2. Дубінський I.О. Проникнення Інтернету в Україні : методологія дослідження. URL: https://inau.ua/ sites/default/files/file/1910/dani_ustanovchyh_ doslidzhen_iii_kvartal_2019_roku.pdf (дата звернення: 02.04.2021).

3. Ершов Ю.М. Феномен фейка в контексте коммуникационных практик. Вестник Толского государственного университета. Филология. 2018. № 52. C. 245-256. URL: https://cyberleninka.ru/article/n/ fenomen-feyka-v-kontekste-kommunikatsionnyhpraktik (дата звернення: 02.04.2021).

4. Курбан О.В. Фейки у сучасних медіа: ідентифікація та нейтралізація. Бібліотекознавство. Документознавство. Інфорлологія. 2018. № 3. С. 96-103. 
URL: http://nbuv.gov.ua/UJRN/bdi_2018_3_15 (дата звернення: 06.04.2021).

5. Братущак О.М., Романюк 0.0. Ядерний удар і магія. Фейки та маніпуляції процвітають в українських медіа. Інститут масової інфорлації. 01 жовтня 2020 p. URL: https://imi.org.ua/monitorings/ yadernyj-udar-ta-magiya-fejky-ta-manipulyatsiyiprotsvitayut-v-ukrayinskyh-media-i35399 (дата звернення: 06.04.2021).

6. Оцінка громадянами діяльності влади, рівень довіри до соціальних інститутів та політиків, електоральні орієнтації громадян (лютий 2020 р., соціологія). Разулков Центр. 20 лютого 2020 p. URL: https://razumkov.org.ua/napriamky/sotsiologichnidoslidzhennia/otsinka-gromadianamy-diialnosti-vladyriven-doviry-do-sotsialnykh-instytutiv-ta-politykivelektoralni-oriientatsii-gromadian-liutyi-2020r (дата звернення: 06.04.2021).

7. Щорічне опитування USAID-Internews «Ставлення населення до ЗМI та споживання різних типів медіа у 2020 p.». URL: https://detector.media/doc/ images/news/archive/2016/181602/2020-MediaConsumption-Survey-FULL-FIN-Ukr.pdf (дата звернення: 06.04.2021).

8. Bruns A., Harrington S., Hurcombe E. "Corona? 5G? or both?": the dynamics of COVID-19/5G conspiracy theories on Facebook. Media International Australia. 2020. № 177 (1). P. 12-29. URL: https:// journals.sagepub.com/doi/full/10.1177/1329878X 20946113 (дата звернення: 06.04.2021).

9. Coronavirus disease (COVID-19) advice for the public: Mythbusters. Fact: 5G mobile networks do not spread COVID-19. World Health Organization. 5 May 2021. URL: https://www.who.int/emergencies/ diseases/novel-coronavirus-2019/advice-for-public/ myth-busters?gclid=EAIaIQobChMIuuOH6fSO8AIVXB DmCh1YLgmREAAYASAAEgJ6tPD_BwE (дата звернення: 06.04.2021).

10. Костельнюк М.М. Маніпуляційні технології в політичних процесах: термінологічний інструментарій. Грані. Том 21. № 5. 2018. С. 123-132.

11. Allcott H., Gentzkow M. Social Media and Fake News in the 2016 Election. Journal of Economic Perspectives. Volume 31. Number 2. Spring 2017. P. 211-236. URL: https://pubs.aeaweb.org/doi/pdfplus/10.1257/ jep.31.2.211 (дата звернення: 06.04.2021).

\section{Анотація}

Ратушна Т. О. Фейки як маніпулятивна технологія формування громадської думки. - Стаття.

У статті розглянуто особливості сучасного інформаційного простору, в якому з появою нових медіа й каналів комунікації відбулись значні трансформації. Особливим чинником цих змін стали соціальні мережі, що прийшли на зміну традиційним медіа (газетам, журналам і телебаченню). Соціальні мережі дозволяють користувачам не тільки споживати інформацію, а й висловлювати свою думку, самостійно створювати й поширювати повідомлення. Значення соціальних мереж в поширенні інформації та формуванні громадської думки постійно зростає, значна частина населення віддає перевагу саме цьому каналу інформації як основному, бо він є в постійному доступі в смартфоні й значно оперативніший, ніж газети й телебачення. Водночас можливість користувачів самостійно продукувати контент і швидко поширювати його спричиняє значну інтенсифікацію комунікативних потоків і погіршення якості інформації. Соціальні мережі - це величезний сегмент комунікативного простору, який має характер саморегульованого середовища, він майже не контролюється та не піддається цензуруванню, неперевірена або спотворена інформація може активно розповсюджуватись і впливати на формування громадської думки. Тож головна складність у користуванні соціальними мережами полягає нині не в тому, щоб знайти певну інформацію чи прочитати актуальні новини, а в тому, щоб визначити, яка інформація є потрібною та правдивою, а яка - шкідливою та спотвореною.

Також соціальні мережі є одним із головних джерел поширення фейків як вигаданих і спеціально сфабрикованих повідомлень, головною метою яких є підрив репутації будь-якого соціального інституту, організації або персони. У такому контексті фейки виступають як маніпуляції, що спрямовані на зміну громадської думки в потрібному для творця чи транслятора напрямі. Якщо розглядати створення та розповсюдження фейків як цілеспрямовану діяльність із метою управління суспільними настроями, що має своєрідну логіку розгортання та містить певну послідовність етапів процедур та операцій, можна вважати, що це маніпулятивна технологія.

У статті на основі теоретичного аналізу й використання конкретних кейсів визначено маркери фейків для їх ідентифікації в інформаційно-комунікаційному просторі й окреслено можливі шляхи запобігання їх поширенню.

Ключові слова: фейк, маніпуляція, дезінформація, маніпулятивна технологія, громадська думка, соціальні мережі.

\section{Summary}

Ratushna T. O. Fakes as a manipulative technology of public opinion formation. - Article.

The article considers the features of the modern information space in which with the advent of new media and communication channels there have been significant transformations. A special factor in these changes was social networks, which replaced traditional media (newspapers, magazines and television). Social networks allow users not only to consume information, but also to express their opinions, independently create and distribute messages. The importance of social networks in disseminating information and forming public opinion is constantly growing, a large part of the population prefers this channel of information as the main one, because it is constantly available on a smartphone and much faster than newspapers and television. At the same time, the ability of users to independently produce content and quickly distribute it, causes a significant intensification of communication flows and deterioration of information quality. Social networks are a huge segment of the communication space that has the character of a selfregulating environment, it is almost uncontrolled and 
not censored, unverified or distorted information can be actively disseminated and influence the formation of public opinion. Therefore the main difficulty in using social networks today is not to find certain information or read current news, but to determine which information is necessary and reliable, and which is harmful and distorted.

Moreover, social networks are one of the main sources of spreading fakes as fictional and specially fabricated messages, the main purpose of which is to undermine the reputation of any social institution, organization or person. In this context, fakes act as manipulations aimed at changing public opinion in the right direction for the creator or translator. If we consider the creation and distribution of fakes as a purposeful activity to manage public sentiment, which has a kind of logic of deployment and includes a certain sequence of stages of procedures and operations, we can assume that this is a manipulative technology. In particular, these study based on theoretical analysis and the use of specific cases, identifies markers of fakes for their identification in the information and communication space and outlines possible ways to prevent their spread.

Kay words: fake, manipulation, misinformation, manipulation technology, public opinion, social networks. 